\title{
An old adaptive radiation of forest dung beetles in Madagascar
}

\author{
Helena Wirta *, Luisa Orsini, Ilkka Hanski \\ Metapopulation Research Group, Department of Biological and Environmental Sciences, P.O. Box 65 (Viikinkaari 1), FI-00014 University of Helsinki, Finland
}

\section{A R T I C L E I N F O}

\section{Article history:}

Received 13 September 2007

Revised 5 February 2008

Accepted 6 March 2008

Available online 15 March 2008

\section{Keywords:}

Scarabaeidae

Helictopleurus

Onthophagini

Oniticellini

Molecular phylogeny

Divergence time

Resource use

Host shift

Resource competition

Range expansion

\begin{abstract}
A B S T R A C T
Adaptive radiations of mammals have contributed to the exceptionally high levels of biodiversity and endemism in Madagascar. Here we examine the evolutionary history of the endemic dung beetle tribe Helictopleurini (Scarabaeidae) and its relationship to the widely distributed Oniticellini and Onthophagini. Helictopleurini species are dependent on mammals for their resources. We date the single origin of the tribe at 37 to $23 \mathrm{MY}$ ago, indicating overseas colonization of Madagascar. The main radiation occurred concurrently with the main radiations of lemurs. The ancestors of Helictopleurini are inferred to have been coprophagous species inhabiting open habitats. Subsequent evolution has involved a shift into forests, changes in resource use to a more generalized diet, and changes in body size. Four species of the extant 65 species have shifted to use the dung of the recently introduced cattle in open habitats, allowing these species to greatly expand their geographical ranges.
\end{abstract}

(c) 2008 Elsevier Inc. All rights reserved.

\section{Introduction}

Much of the biological diversity on Earth has arisen during relatively short periods of time in rapid radiations, which have generated suites of related species from a single ancestor. In the case of adaptive radiations (Schluter, 2000), the new species have evolved to dissimilarly use a range of resources, which has increased the long-term viability of the new taxa. Oceanic islands and archipelagos provide particularly informative situations for the study of adaptive radiations (Emerson, 2002). The high or relatively high species diversity and endemism on large oceanic islands is often the result of adaptive radiations, though multiple colonizations from continents or other islands and speciation due to vicariant events may have further increased diversity. Well-studied examples of adaptive radiations on islands and sets of islands include the Darwin's finches on the Galapagos islands (Sato et al., 2001; Schluter, 1996), the Anolis lizards in the Caribbean (Losos, 1990a,b; Losos and Irschick, 1996), Hawaiian silverswords (Baldwin, 1997; Barrier et al., 1999) and Hawaiian Schiedea plants (Sakai et al., 1997; Weller et al., 1990).

Madagascar is the world's fourth largest island with a great variety of climates and habitats. Madagascar has been isolated for 160-158 MY from mainland Africa and 80 MY from India (Brig-

\footnotetext{
* Corresponding author. Fax: +358 919157694.

E-mail address: helena.wirta@helsinki.fi (H. Wirta).
}

gs, 2003; de Wit, 2003), and it has consequently an exceptionally high level of endemism at different taxonomic levels, making it one of the hottest biodiversity hotspots on Earth (Myers et al., 2000). Madagascar's biota includes many examples of apparently adaptive mammalian radiations, involving lemurs (Yoder and Yang, 2004), nesomyine rodents, tenrecs and carnivorans (Poux et al., 2005). These taxa have colonized Madagascar probably only once by overseas dispersal after the break-up from other continents (Poux et al., 2005). Geckos, chameleons and tortoises have radiated in Madagascar and further dispersed to other Indian Ocean islands and mainland Africa (Austin et al., 2004; Palkovacs et al., 2002; Raxworthy et al., 2002), while colubrid snakes and hyperoliid frogs have colonized Madagascar multiple times (Monaghan et al., 2005; Nagy et al., 2003; Vences et al., 2003). Vicariance appears to have led to speciation following the Gondwanian breakup in e.g. boid snakes, podocnemid turtles, iguanid lizards and freshwater fishes (Noonan and Chippindale, 2006; Sparks and Smith, 2004). In contrast, little is known about the evolutionary history of invertebrates in Madagascar. The best studied groups include butterflies (Torres et al., 2001; Zakharov et al., 2004), ants (Fisher, 1997) and small minnow flies (Monaghan et al., 2005), which appear to have colonized Madagascar more than once, though there are no estimates of the time of colonization or radiation. Considering all the Malagasy faunal and floral groups, longdistance dispersal appears to be the most common way of origin (Yoder and Nowak, 2006). 
The dung beetle family Scarabaeidae has a worldwide distribution with some 27,800 described species (Cambefort, 1991a; Jameson and Ratcliffe, 2005). Dung beetles play an important role in many ecological processes, especially in nutrient cycling and fertilization and aeration of soils, but also in seed dispersal and the dynamics of some parasite species (Andresen, 2002a,b; Mittal, 1993). The phylogenetic relationships within Scarabaeidae have been recently studied, but they remain largely unresolved (Browne and Scholtz, 1995, 1998; Cabrero-Sanudo and Zardoya, 2004; Monaghan et al., 2007; Philips et al., 2004; Smith et al., 2006; Villalba et al., 2002). There is only one study of the Malagasy dung beetles (Orsini et al., 2007), examining the molecular evolution of the two main groups of dung beetles in Madagascar.

The ancient isolation of Madagascar is reflected in the composition of its dung beetles, which lack the evolutionarily younger tribes that have become to dominate in abundance the older tribes elsewhere in the world, with the partial exception of the Neotropical region (Davis and Scholtz, 2001). In Madagascar, the vast majority of dung beetles belong to only two tribes, Helictopleurini and Canthonini. The former is completely endemic to Madagascar, while the latter is endemic at the generic level. Helictopleurini has two genera, Heterosyphus and Helictopleurus, the first of which is monotypic while the second one has 64 species and subspecies (Lebis, 1960; Montreuil, 2005a,b, 2007). The tribe is diverse (Paulian and Cambefort, 1991), and the species have been divided into nine morphological groups (Lebis, 1960; Montreuil, 2005b). The genus Helictopleurus was first described within Oniticellini (d'Orbigny, 1915), but it has subsequently been elevated to the level of the subtribe Helictopleurina and to the tribe Helictopleurini (Lebis, 1960; Montreuil, 2005a,b; Paulian, 1986). According to recent phylogenetic studies (Philips et al., 2004; Villalba et al., 2002), Onthophagini, Oniticellini, and Onitini are the closest tribes to Helictopleurini. The current taxonomy and limited molecular evidence (Monaghan et al., 2007) suggest that Oniticellini is the closest taxon to Helictopleurini.

The Malagasy Canthonini consists of 13 genera and ca. 170 species (Montreuil, 2006; Paulian, 1975). Other tribes of Scarabaeidae in Madagascar include three genera of Scarabaeini, each with one endemic species, and six species of Onthophagus (Onthophagini), two of which are introduced and four are endemic (Davis and Scholtz, 2001; Lebis, 1960).

The primary resource for dung beetles worldwide, large herbivore dung, is very limited in Madagascar, as native ungulates apart from the now extinct hippopotami have been completely lacking and the largest mammals are primates (lemurs). The largest Malagasy herbivores, including gorilla-sized lemurs, hippopotami, giant tortoises and the elephant bird, have gone extinct in the past 2000 years (Burney et al., 2004), but they can be expected to have contributed to the radiation of dung beetles. Most recently, in the past 1500 years, humans have introduced the new resource of cattle dung, which is now plentiful especially in open areas.

In a previous study, Orsini et al. (2007) examined the molecular evolution of all Malagasy dung beetles using 7 gene regions and a sample of 44 species, including 17 Helictopleurini species. Here we focus on the evolutionary history of Helictopleurini with a large sample of individuals, and reconstruct a molecular phylogeny for about half of the described species, representing all the morphological groups (Lebis, 1960). We include in the analysis a representative sample of 24 species of the presumed sister tribes of Helictopleurini. We investigate the adaptive radiation in Helictopleurini by addressing the three criteria listed by Schluter (2000): single origin, one or more periods of rapid speciation, and evolution of traits that facilitate the fit of the species to their environment. Single origin would be supported by monophyly of Helictopleurini. Times of divergence are estimated based on mtDNA sequences, and these estimates are used to describe the temporal pattern of speciation, also in relation to the known times of radiation in the relevant mammalian taxa. Using data on body sizes, resource use and positions and sizes of geographical ranges, we describe the likely pattern of ecological differentiation. Finally, we describe a recent shift of resource use by a small number of species to cattle dung and the apparent ecological and possible evolutionary consequences of that shift.

\section{Materials and methods}

\subsection{Sampling}

We have conducted and organized trappings of dung beetles in 40 forest localities across Madagascar in the years 2002-06 (Fig. 1). Beetles were trapped with standard baited pitfall-traps (plastic cups, $1.5 \mathrm{dl}$ ), over which a large leaf was placed to prevent rain water entering the trap. The traps were filled up to one third of their volume with water containing some washing-up liquid to decrease water tension. A bait of fish, chicken intestine or primate

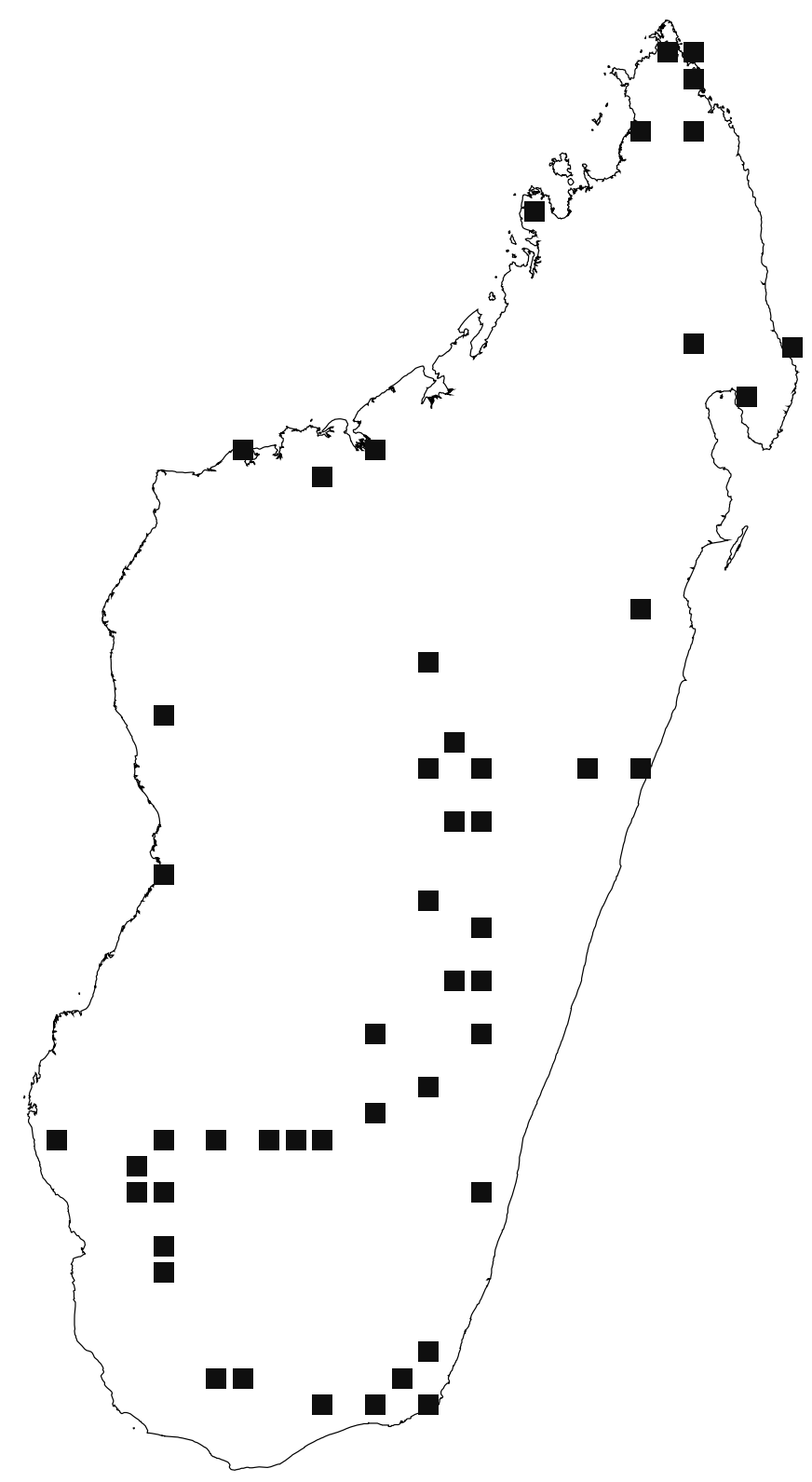

Fig. 1. Trapping localities in the sampling of Helictopleurini. 
dung (ca $3 \mathrm{~cm}^{3}$ in volume) was wrapped in gauze and the bundle was hanged from a stick above the trap. Minimally 40 pitfalls per locality were operated for $48 \mathrm{~h}$. In two localities, Ranomafana National Park (NP) and Masoala NP, intensive trappings have been conducted for several years and weeks, respectively, with many different bait types, including dung of several lemur species, at several altitudes and in different types of forest as well as in open habitats (Viljanen et al., in preparation). In most other forest localities trappings have been done by local assistants and forest reserve personnel. In open habitats, cattle dung pats have been examined for dung beetles in more than 50 additional localities across Madagascar (Rahagalala et al., in preparation). As many of the uncollected species may already be extinct (Hanski et al., 2007), our sample includes the clear majority of the existing species.

The species have been identified by Wirta, Montreuil and Viljanen based on comparison with type specimens and series in the Paris National Museum of Natural History. We have examined the collections in Paris for additional taxonomic and sampling data. These collections include the majority of the described species of Helictopleurini (56 species) and almost all type specimens. To investigate the sister groups of Helictopleurini, we included in the molecular analyses a range of species of Onthophagini, Oniticellini, Onitini and Coprini from Africa and Asia (Appendix A).

\subsection{DNA extraction and sequencing}

Beetles were preserved in 95\% ethanol at the site of sampling. We sequenced one mitochondrial (cytochrome oxidase subunit I, COI) and two nuclear (28S and 18S rRNA) regions for three individuals of each sampled species of Helictopleurini, if available, and for one or two individuals per species of the other tribes. An additional mitochondrial region (16S) was sequenced for three individuals of Helictopleurini species, and yet another mitochondrial region (cytochrome oxidase $b, \mathrm{Cyt} b$ ) for one individual of all species. Sequences have been submitted to GenBank (accession numbers in Appendix A). The protocols used for DNA extraction, amplification and sequencing are the same as in Orsini et al. (2007). The primers are also the same as in Orsini et al. (2007) (Cytb with primers CytbB3 and CytbB4), with the exception of COI, for which primers Pat (5'-TCCAATGCACTAATCTGCCATATTA-3') and Jerry (5'-CAA CATTTATTTTGATTTTTTGG-3') were used (Simon et al., 1994).

\subsection{Phylogenetic analyses}

The sequences were aligned with Clustal W (Thompson et al., 1994) in Bioedit 7.0.1 (Hall, 1999) and adjusted by eye. Copris confucius (Coprini, Scarabaeidae) was used as an outgroup, as Coprini are considered to be most distinct among the tribes included in this study (Davis et al., 2002). Data were first examined by analyzing the different gene regions separately with parsimony (NONA with 1000 replicates; Goloboff, 1999). As all individuals for each species clustered together for each gene region, consensus sequences for each species were created with BioEdit 7.0.1 (Hall, 1999) to include possible variation within species. Individual sequences were examined by calculating the numbers of conservative, variable, parsimony informative and singleton sites by MEGA 3.1 (Kumar et al., 2004). The results are presented in Appen$\operatorname{dix} B$.

In the final phylogenetic analysis either a sequence for one individual or a consensus sequence for the species was used. The five regions (18S, 28S, COI, Cytb, and 16S) were analyzed together, according to the total evidence principle (Kluge, 1989), as this approach yielded the highest explanatory power in the previous analyses (Orsini et al., 2007). The alignments of the different gene regions were concatenated in WinClada (Nixon, 2002). We used the Bayesian approach as implemented in MrBayes 3.1.2 (Ronquist and Huelsenbeck, 2003), which takes into account information in the polymorphic sites by treating them as uncertain between the possible bases. The evolutionary models were chosen based on the Hierarchical Likelihood Ratio Test with Model Test 3.06 (Posada and Crandall, 1998). In the analysis, three million generations were run with three cold and one heated chain, sampling every 1000th generation, with two simultaneous runs. The parameter values and the trees that were sampled were summarized after discarding the topologies that occurred prior to the stabilization of the likelihood value (burn-in). The analysis was run three times to ensure topological convergence and homogeneity of posterior clade probabilities.

To estimate times of divergence we used the two protein coding mitochondrial regions $\mathrm{COI}$ and Cytb with one individual per species. We assumed the rates of evolution of 0.0075 and 0.012 substitutions/site/MY to cover the range of rates reported (Farrell, 2001; Juan et al., 1995) and used for Coleopteran COI region in the literature (Brower, 1994; Leys et al., 2003; Ribera and Vogler, 2004; Smith and Farrell, 2005). The rates estimated for the Coleopteran COI region, which is exactly the same region as used here, are based on pooled codon positions and a time range of 1-20 MY (Farrell, 2001; Juan et al., 1995). As the level of variability (Appendix B) and the evolutionary models suggested by Modeltest for the COI and $C y t b$ regions were comparable, we pooled these two regions in the estimation of divergence times.

The timing analysis was done with BEAST 1.4 (Drummond and Rambaut, 2002-2006), which uses Bayesian MCMC estimation. We used the model GTR $+\mathrm{I}+\mathrm{G}$ for the concatenated COI and Cytb sequence matrix. We assumed the relaxed-clock model and uncorrelated rates for each branch, drawn independently from a lognormal distribution, as this model has superior performance among the alternative models available (Drummond et al., 2006). We used the topology inferred from the Bayesian analysis as the fixed topology, including Helictopleurini and Oniticellus planatus, the closest relative available. We estimated the time of divergence of Helictopleurini from $O$. planatus and used the TMRCA statistics to estimate the time of the most recent common ancestor for two sets of Helictopleurini taxa, one including all the species and the other one including the clades II and III in the Bayesian phylogeny (below, Fig. 4). To elucidate the rate of speciation through time, we estimated the times of all branching events using TMRCA statistics and assuming the rate of 0.012 substitutions/site/MY. The analyses were run for 30 million generations and the results were examined with TRACER 1.0.1 (Rambaut and Drummond, 2003). Finally, the entire analysis was repeated three times to verify the consistency of the time estimates across multiple runs.

\subsection{Ecological traits}

Distributional data for Helictopleurini include all the sampling localities of specimens in the collections of the Paris National Museum of Natural History and the data gathered during the present project. The locality data were recorded with accuracy of $0.50^{\circ}$ or $0.25^{\circ}$ depending on the site. Distributional maps for Helictopleurini were created with ArcView GIS 3.1 (Environmental Systems Research Institute, Inc.). The size of each species' range was approximated as the distance between the two most distant sampling localities.

Body size was calculated as the average of the maximum and minimum lengths in the literature (Lebis, 1960; Montreuil, $2005 a, b)$ or by measuring individuals of rare species following the same criteria.

Data on food resource use were mostly obtained from intensive ecological studies in two forest localities in Ranomafana NP (Koivulehto, 2004; Viljanen, 2004) and in Masoala NP (unpubl. data), in which extensive pitfall-trappings have been conducted using 
several bait types (fish, meat, chicken intestine and dung of several primate species). Additional data have been collected with smallscale trappings in Andasibe NP, Ambila and Manombo (unpubl. data). The other trappings across Madagascar have been conducted with carrion, though in some localities lemur dung has also been used. Cattle dung pats in open areas have been searched for dung beetles in more than 50 localities in eastern and southern Madagascar (Rahagalala et al., in preparation).

Based on the above data, species were classified according to their food resource use into the following categories: primate dung specialists, cattle dung beetles, carrion specialists or generalists, and unknown. Species classified as primate dung specialists have a strong preference for primate dung, such that more than $90 \%$ of individuals have been caught with primate dung. Cattle dung beetles have been sampled mostly in cattle dung in open areas. This category includes species able to feed on ungulate dung, which has a very different texture as compared with the dung types previously available in Madagascar. Carrion specialists or generalists have been caught only with carrion or both with carrion and dung. A species was classified as having unknown food resource use if less than 10 individuals have been sampled. A large proportion of the species falls into the category of carrion specialists or generalists. In many cases they have been sampled in large numbers with carrion-baited pitfalls only, but if their ranges are located in areas where trappings with other bait types have not been conducted it is possible that they are generalists rather than carrion specialists.

\section{Results}

Our sampling in 2002-06 yielded 30 of the 65 previously described species of Helictopleurini as well as 4 new species, of which 27 species were available for sequencing. The 34 species that we have recorded have wider geographical ranges than the unrecorded species ( $t$-test, $P=0.03 ; n=56$ species), and the former species tend to have more historical sampling localities ( $t$-test, $P=0.05$, without the new species; Fig. 2). These results suggest that we have been able to sample most of the common Helictopleurini species.

Some of the species not sampled by us may be more specialized in their diet, but most of them are probably simply rare. Hanski et al. (2007) found that forest loss has been more severe within the ranges of the species that have not been sampled by us than within the ranges of the species we have sampled, suggesting that deforestation may have already caused the extinction, or effective extinction, of some of the unrecorded species, most of which have not been seen for 50 years or more (Hanski et al., 2007). In any case, our sample of 27 species covers the full range of morphological variation in the tribe, as all but one monotypic group of the nine morphological groups of Lebis (1960) are represented (Appendix A).

\subsection{Phylogenetic analyses}

The phylogenetic analyses are based on 2608 aligned basepairs. Approximately half of the data consist of nuclear sequences (1132 bp). The five gene regions differ markedly in the level of variation, the nuclear regions being much more conservative than the mitochondrial regions (Appendix B). Different evolutionary models explained best nucleotide variation in the different genomic regions: $\mathrm{TrNef}+\mathrm{I}+\mathrm{G}$ for $28 \mathrm{~S}, 18 \mathrm{~S}$ and $16 \mathrm{~S}, \mathrm{GTR}+\mathrm{I}+\mathrm{G}$ for $\mathrm{COI}$, and $\mathrm{GTR}+\mathrm{G}$ for Cytb. To implement the appropriate models for different data partitions, we used the Bayesian program MrBayes (Ronquist and Huelsenbeck, 2003). For the regions 28S, 18 S and 16S two types of substitutions were used, while six types were used for COI and Cyt $b$. The gamma distribution was estimated separately for each region. Maximum likelihood and maximum parsimony have the

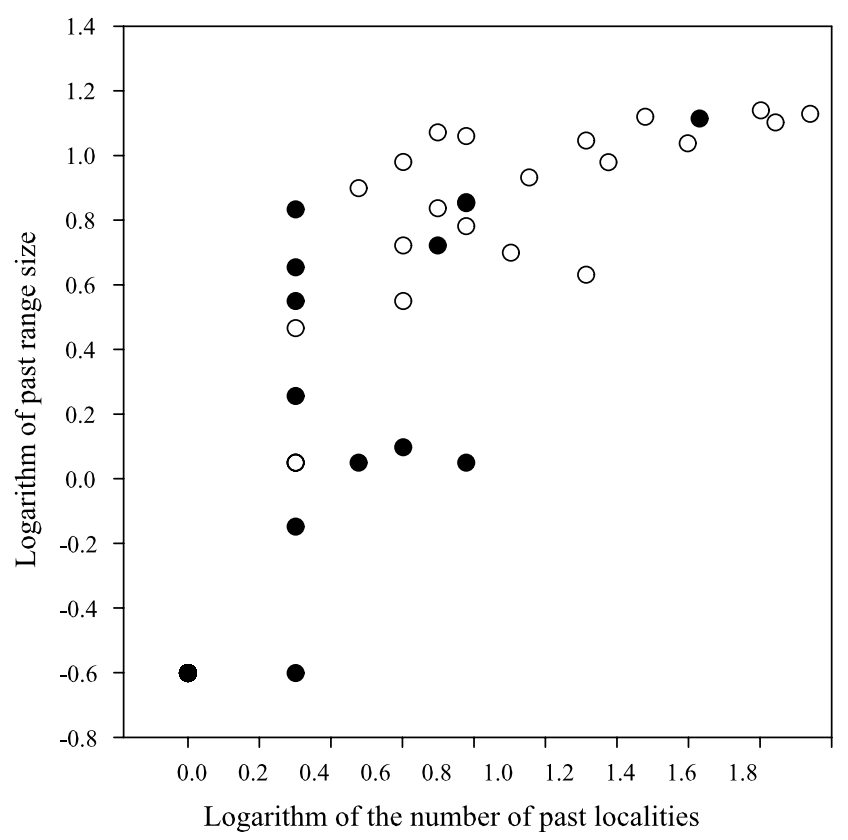

Fig. 2. The size of the past geographical range (calculated for historical sampling localities) plotted against the number of historical sampling localities in species sampled during this study (open circles $\bigcirc$ ) and in species that have remained unrecorded (black dots $\bullet$ ).

limitation that they are restricted to a single model of evolution within one analysis. This is a significant limitation when combining data from different gene regions with potentially very different evolutionary dynamics (Tello and Bates, 2007).

The majority rule consensus Bayesian tree (Fig. 3) supports the following relationships among the tribes. The tribe Coprini, of which one species was used as an outgroup, is strongly supported as separate from the other tribes (posterior probability 1.00). The two clades branching off next include eight African Onthophagini, with high support for both clades as well as for the node separating them from the other Onthophagini and Oniticellini. Working towards the more derived clades, the small clades including species from the tribes Onthophagini, Oniticellini and Onitini have poor statistical support at the base but high support at the tip nodes. These clades include species from both Africa and Asia as well as Onthophagini from Madagascar (Fig. 3).

Helictopleurini comprise a strongly supported monophyletic clade (posterior probability 1.00), suggesting a single origin for the tribe. The closest taxon to Helictopleurini is Oniticellus planatus (Oniticellini), which clusters together with three Oniticellini species. Within Helictopleurini, most nodes are well supported (clades I-IV in Fig. 4), including the tip nodes.

There are altogether six species of Onthophagini known from Madagascar, of which four species are considered to be endemic. One of them, Onthophagus elegans, is included in the above-mentioned mixed set of clades close to Helictopleurini. The other endemic species, $O$. hinnulus, is supported as the closest species to the introduced $O$. depressus, and these two species, with the introduced 0 . gazella, are placed within the Onthophagini groups that are basal in our phylogeny.

The phylogeny is largely congruent with the morphological species groups as defined by Lebis (1960) and Montreuil (2005b). The groups giganteus, fasciolatus and semivirens are as defined by the morphological criteria. The groups fungicola and viridiflavus are combined, as also suggested by the identification key of Lebis, and so are the morphologically very similar groups splendidicollis and quadripunctatus. Both of the combined groups 


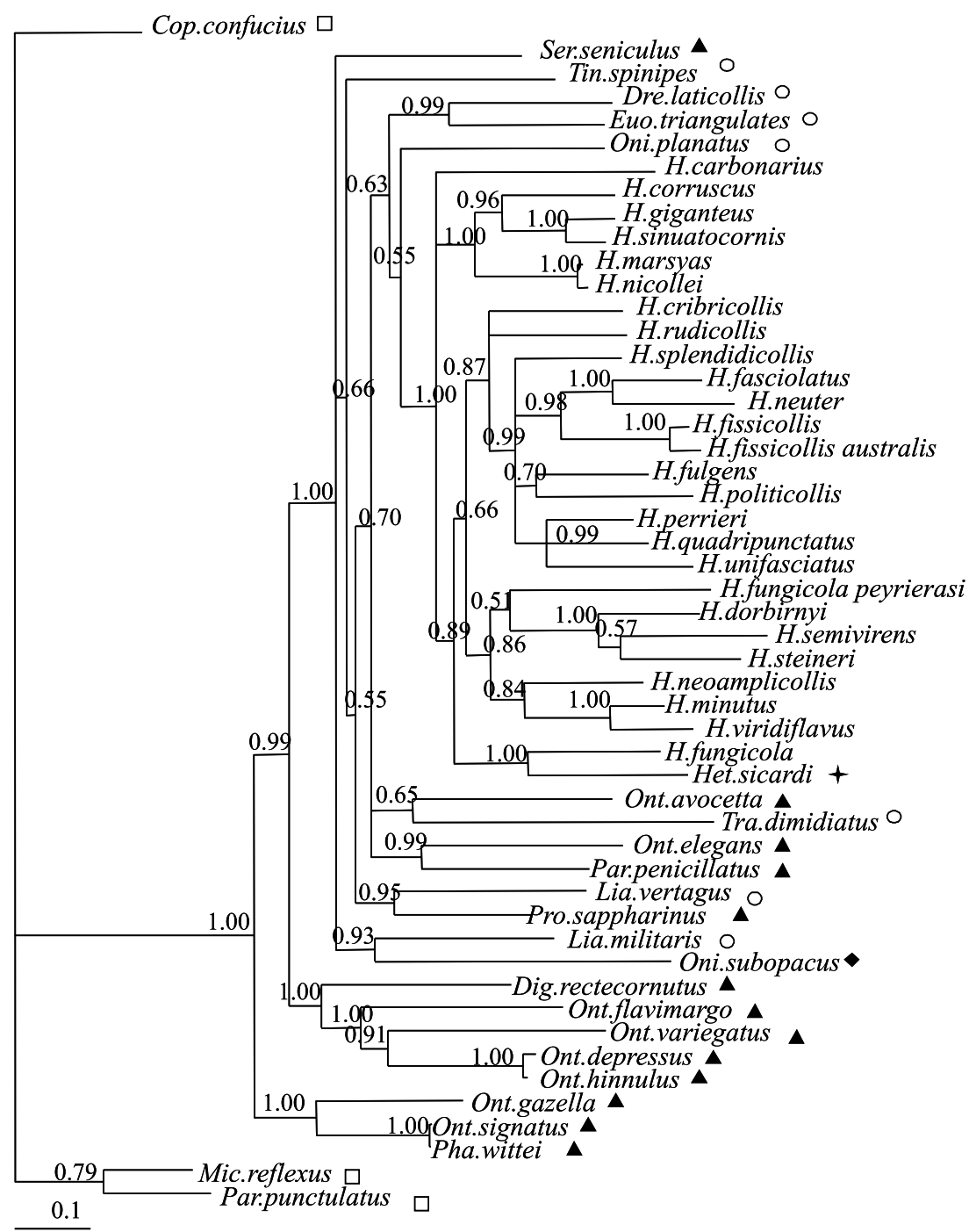

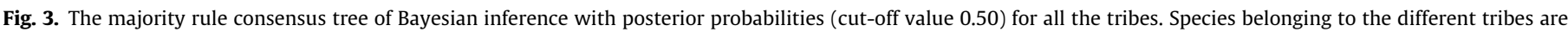

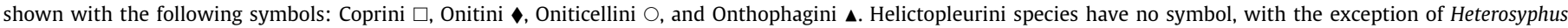
sicardi, marked with a cross +.

are paraphyletic. The morphological group rudicollis, with only two species included in the present study, is not supported by the phylogeny. The monotypic genus Heterosyphus is placed among Helictopleurus, in the group fungicola.

Eight putative sister species pairs are supported by the phylogeny. Of these, three pairs (marsya-nicollei, sinuatocornis-giganteus, fissicollis-fissicollis australis) have definite morphological support as the closest extant species to each other, but for the others it is difficult to establish evident relationships (Montreuil, pers. commun., 2007). The phylogeny clearly contradicts the subspecific status of $H$. fungicola peyrierasi (Montreuil 2005a).

\subsection{Times of divergence}

The estimated time of divergence of Helictopleurini from 0 . planatus is $44(29 / 64)$ and 28 (18/39) MY for the rates of 0.0075 and 0.012 substitutions/site/MY, respectively (upper and lower 95\% credibility limits in brackets). The time since the most recent common ancestor of all Helictopleurini species was estimated as 37 (27/47) and 23 (17/29) MY for the two rates, respectively. The most recent common ancestor of the subset of Helictopleurini including the more derived species (clades II and III, Fig. 4) was estimated to have occurred 34 (25/44) and 21 (16/27) MY ago, suggesting that the radiation of Helictopleurini started soon after the colonization of Madagascar, though admittedly the 95\% credibility intervals are rather wide.

Fig. 5 shows the lineage-through-time plot (Nee et al., 1992), the cumulative number of branching events since the ancestor of Helictopleurini split from its closest relative. The graph is based on mean estimates. Following the first branching event within Helictopleurini, estimated to have occurred 5 MY after the split with Oniticellini, the rate of new species appearing started to increase, was highest between 20 and $10 \mathrm{MY}$ before present, and slowed down afterwards. This plot includes only about half of the described Helictopleurini species, but considering the good coverage of the morphological variation within the tribe Fig. 5 can be considered as a reasonable approximation.

\subsection{Evolution of ecological traits}

Based on the molecular phylogeny in Fig. 4, body size is a conservative trait in Helictopleurini. The four major clades in the Bayesian phylogeny show highly significant differences in body size (Fig. 4, ANOVA, $P<0.001$ ). There is significant variation in body 

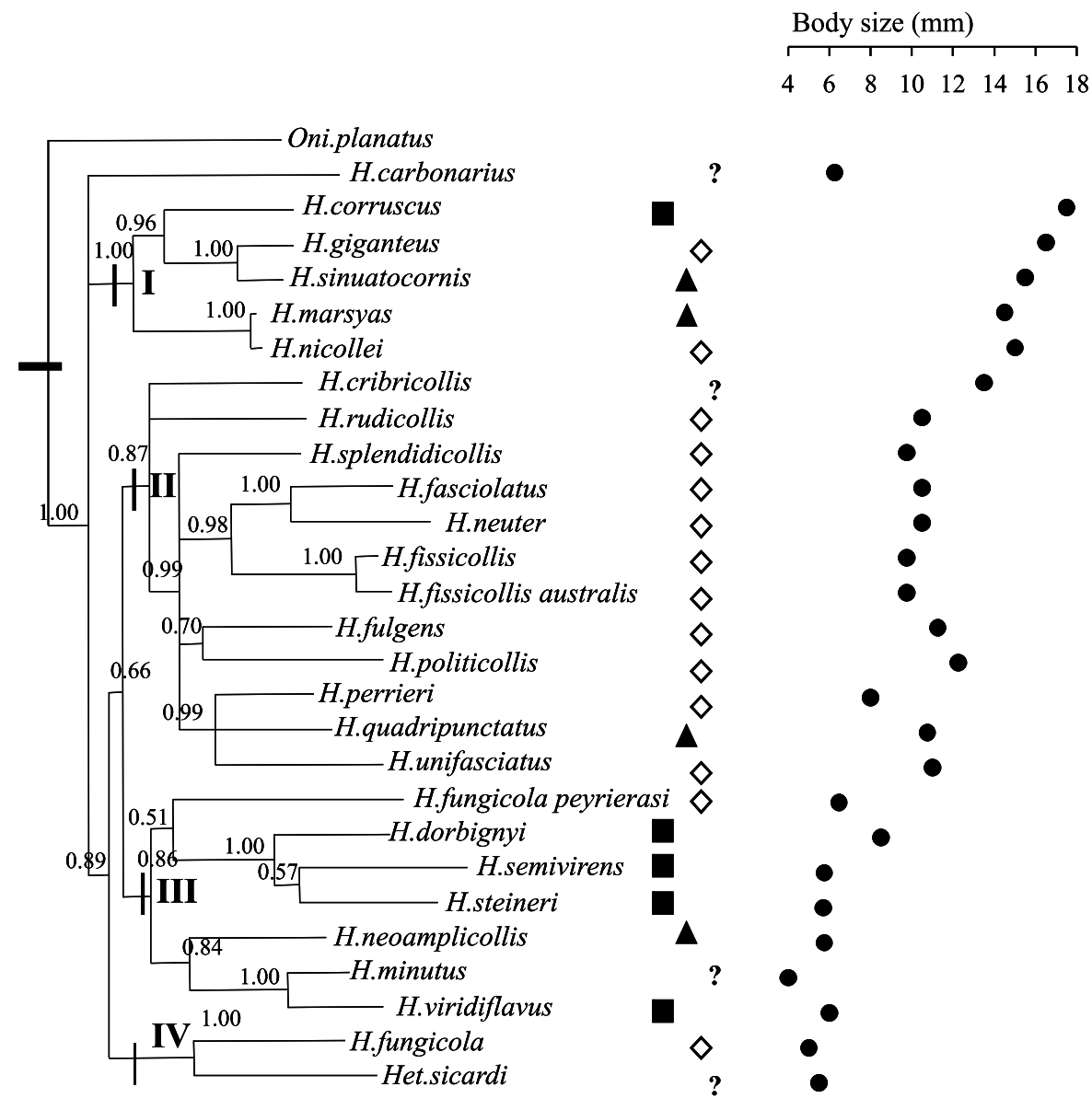

0.1

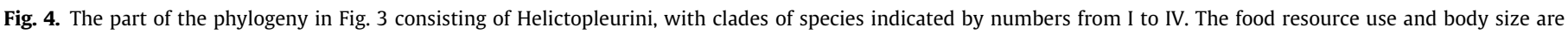

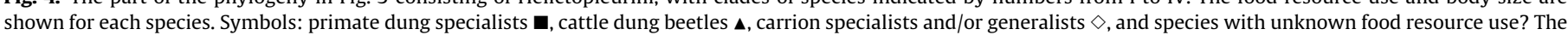
black dots show the average body size of each species (scale in $\mathrm{mm}$ ).

size also among the morphologically defined groups of Lebis (1960) (groups fungicola-viridiflavus and splendidicollis-quadripunctatus combined; ANOVA, $P<0.001$ ), though here of course body size may have been used as one of the traits to define the groups in the first place.

Helictopleurini occurs in three major habitat types in Madagascar. Forty-one species occur in wet forests in eastern Madagascar, while eight species are found in the various types of dry and seasonal forests in western Madagascar. Nine species are distributed across the island, of which four species occur in various forest types and five species use mainly or exclusively the open and dry habitats (cattle dung beetles, of which four are considered below; $H$. littoralis is rare and poorly known). There is no detectable phylogenetic signature in the distribution of species among the three main habitat types.

Concerning the feeding habits of the species, the clades differ in the resource use of their species $\left(\chi^{2}, P=0.03\right)$. Clade III with the smallest species includes four of the five species that are specialized on primate dung (Fig. 4). Most of the remaining species were classified as 'carrion specialists or generalists', and they are particularly common in the large derived clade II (Fig. 4). Four species are cattle dung beetles, and exceptionally for Helictopleurini, they occur in open habitats, where also most of the cattle is present. One of the four species (H. quadripunctatus) has been recorded to use other resources, whereas the other three species are specialized on cattle dung (>95\% of individuals caught from cattle dung). Two of the four cattle dung beetles belong to the giganteus group and are in the clade I (though not sister taxa), whereas the other two cattle dung beetles are not closely related (Fig. 4).

Resource use is related to body size to the extent that four of the five primate dung specialists are small and smaller than most of the other species. The generalists are of various sizes, though most are medium-sized, and among the cattle dung beetles one species is small, one is medium-sized, and two are large. The two large ones are closely related (above), and intriguingly one of them is rare, while the remaining three cattle dung beetles are all exceptionally abundant.

The sizes of the species' geographical ranges vary greatly, but there are no significant differences among the four clades in Fig. 4 (ANOVA, $P=0.15$ ). The average range size (maximum distance between two sampling localities) is $490 \mathrm{~km}$, excluding the four cattle dung beetles, for which the average range size is $1390 \mathrm{~km}$, in practice most of Madagascar (Fig. 6). Indeed, the cattle dung beetles have significantly larger ranges than species with other feeding habits $(t$-test, $P=0.01)$. The different clades are not restricted to any particular part of Madagascar, as they do not differ in terms of the average latitude and longitude of the sampling localities (ANOVA, $P=0.04$ and $P=0.48$; the marginally significant result for latitude is due to clade IV with only two species, which do not occur in eastern Madagascar). 


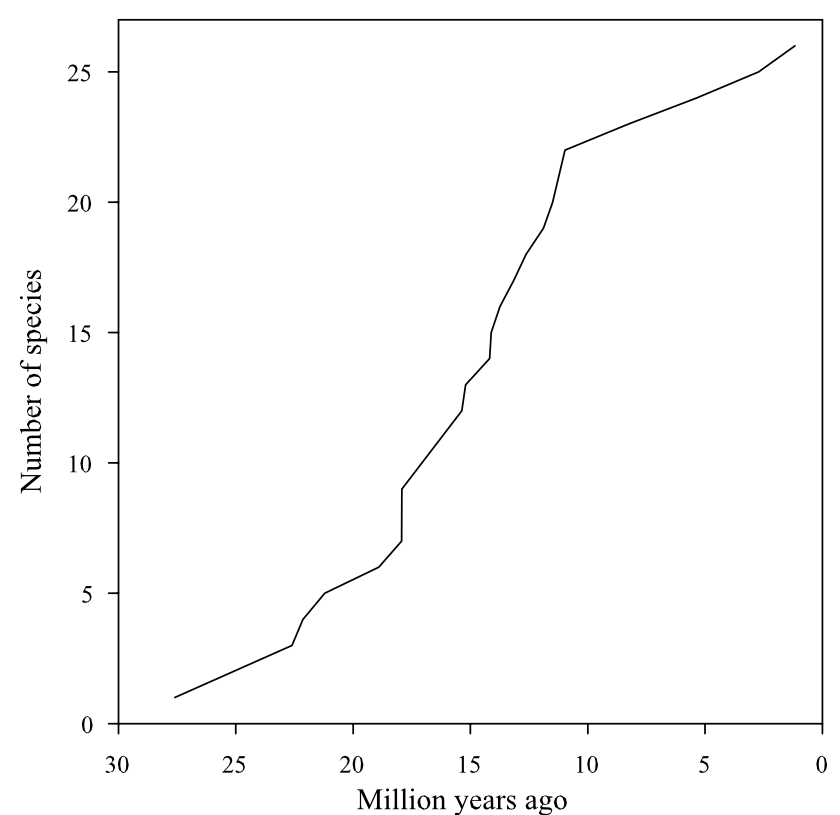

Fig. 5. The cumulative number of species through time, illustrating changes in the rate of speciation. The time estimates for the nodes in the phylogeny in Fig. 4 are based on Bayesian inference assuming the mean rate of 0.012 substitutions/site/ MY

\section{Discussion}

\subsection{Colonization of Madagascar}

Helictopleurini is strongly supported as a monophyletic taxon. The closest relatives in our phylogeny are three Oniticellini species, consistent with the taxonomy of Lebis (1960) and the recent molecular phylogeny of Scarabaeinae (Monaghan et al., 2007). The closest species to Helictopleurini in our study are from Africa and Asia, while in the phylogeny of Monaghan et al. (2007) the sister group of Helictopleurini includes species from Africa, Asia and Europe (our study did not include species from Europe). In both Monaghan et al. (2007) and in the present study Helictopleurini stem from within Oniticellini, suggesting a subtribal status for Helictopleurini.

Neither Onthophagini nor Oniticellini are monophyletic in our results, with one Onitini species branching off within the two tribes. The relationships of the three tribes were not resolved in the consensus tree of Philips et al. (2004), whereas in the phylogeny of Monaghan et al. (2007) Onitini formed a clade of its own, Helictopleurini grouped with Oniticellini, and Onthophagini was paraphyletic. Onthophagini and Oniticellini have been traditionally distinguished by two morphological characters (number of antennal articles and visibility of scutellum), but both character states have been observed for the two characters in both tribes (Cambefort, pers. commun. 2006). There is a need for a thorough revision of Onthophagini and Oniticellini, including Helictopleurini's possible status as a subtribe of Oniticellini.

The time of divergence of Helictopleurini from its closest relatives has a date range from 44 to $28 \mathrm{MY}$ in our results (Table 1 ). The actual time of colonization is likely to be closer to the present, as the estimated time for the most recent common ancestor of Helictopleurini is from 37 to 23 MY. These estimates are consistent with current views about the evolution of such "modern" dung beetle tribes as Scarabaeini and Onthophagini, for which the oldest fossils are approximately 40 MY old (Cambefort, 1991b).

The timing estimates broadly correspond to the arrival and radiation of the main mammalian groups in Madagascar. Lemurs first arrived 65-60 MY ago (Poux et al., 2005; Yoder and Yang, 2004), and their main radiations took place 43-29 MY ago (Table 1). Carnivores, rodents, and tenrecs colonized Madagascar in the time interval from 42 to 19 MY (Poux et al., 2005) and radiated 30-

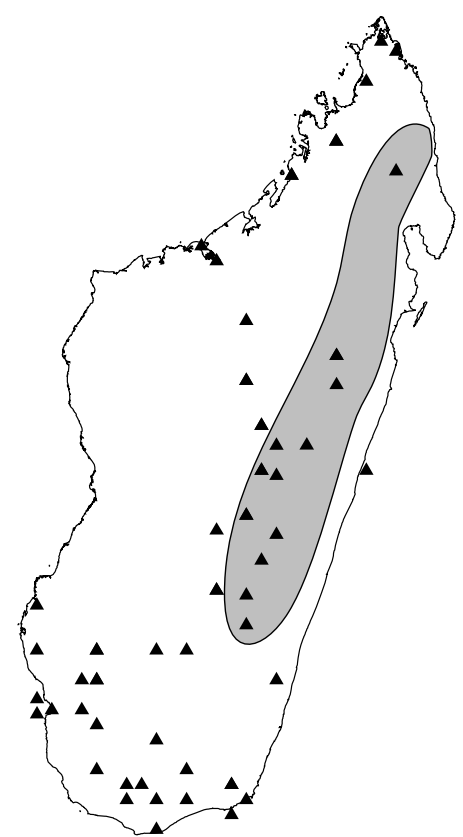

- H.marsyas

- H.corruscus

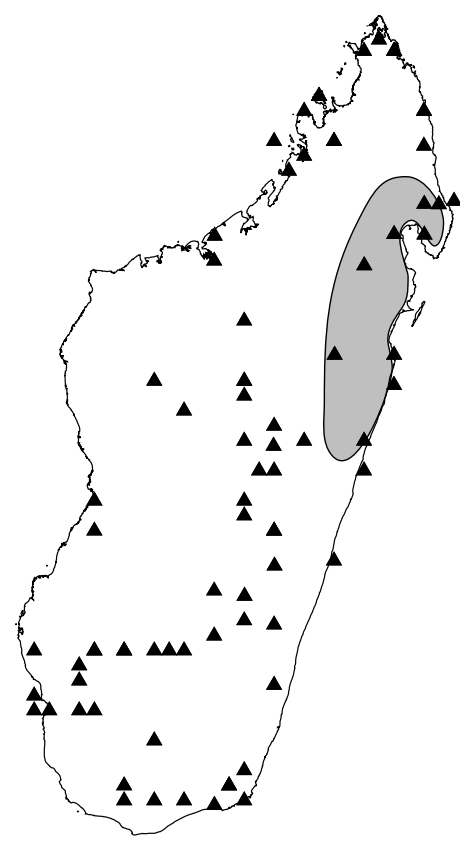

\. H.quadripunctatus

O H.neuter

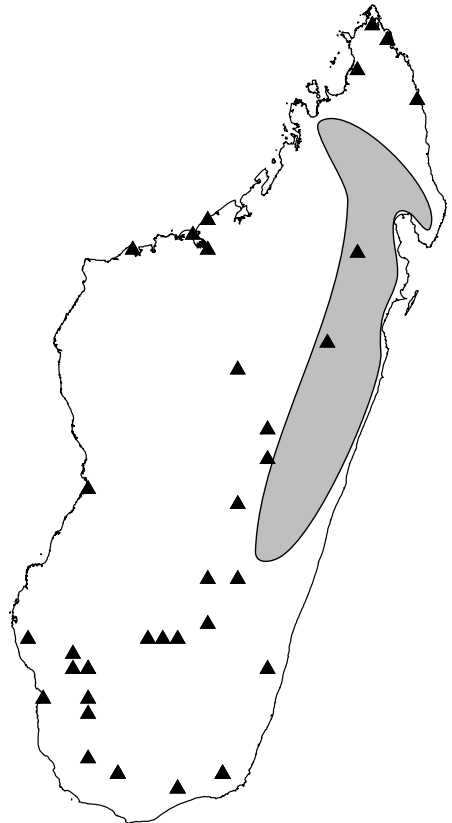

\ H.neoamplicollis

○ H.viridiflavus

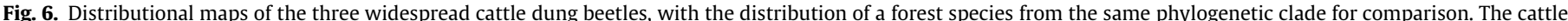

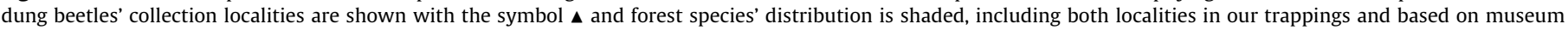
records. 
5 MY ago (Table 1). All these taxa, including Helictopleurini dung beetles and mammals, must have dispersed across the ocean, as no geologically supported land connections were present at the time of colonization (Noonan and Chippindale, 2006): the breakup of Madagascar from Africa (160 MY) and India ( 80 MY) occurred earlier, as did the hypothetical land bridge to Antarctica ( $80 \mathrm{MY}$ ).

The present estimates of the time of divergence differ from those given by Orsini et al. (2007), who put the divergence of Helictopleurini at 8.6 MY ago. The previous calculation was based on five mtDNA regions, including both protein coding and ribosomal regions. The present estimates are based on the two protein coding mtDNA regions for which rate estimates are available for beetles (Farrell, 2001; Juan et al., 1995). Additionally, here we incorporate the closest outgroup in the estimation, using an evolutionary model appropriate for the two gene regions. We consider that the present estimates are superior to those presented in Orsini et al. (2007).

\subsection{Adaptive radiation}

Helictopleurini has undergone an adaptive radiation in Madagascar. First, a single origin is highly probable due to the monophyly of the tribe. Second, the rate of speciation appears to have peaked early in the radiation, based on the lineage-through-time plot. As only half of the described species could be included in the phylogeny, early acceleration in the rate of lineage splitting cannot be verified. However, our sample of species covers the entire range of morphologies and is thus a good approximation of the entire tribe. The analysis of Hanski et al. (2007) suggested that a large number of the species not included in our sample may have already gone extinct, or effectively extinct, due to extensive deforestation, with no taxonomic or phylogenetic bias in the apparent extinctions. Concerning the mode of speciation, the sister species pairs in the present phylogeny have non-overlapping ranges, consistent with allopatric speciation.

Third, Helictopleurini have diverged in terms of body size, habitat selection, and food resource use, which all undoubtedly facilitate their coexistence. Tropical forest dung beetle communities are highly competitive (Hanski, 1989; Hanski and Cambefort, 1991), and the communities in Madagascar are no exception (Viljanen et al., in preparation). Competition has been shown to promote adaptive radiation in insects (Despres and Cherif, 2004).

Some of the distributional patterns in Helictopleurini are best explained by competition. First, all species in clade II are medium-sized generalists and/or carrion specialists, are hence likely to compete with each other, and only a few of them co-occur in the same locality (own observations). Second, the exceptionally large ranges of the species that have recently shifted to cattle dung are likely to reflect competitive release (discussed below). And third, the fact that Onthophagini have not colonized forests in Madagascar (below), though they occur commonly in forests elsewhere in the tropics, suggests that Helictopleurini have radiated to effectively fill the 'Onthophagini niche' in Malagasy forests. In summary, we conclude that Helictopleurini speciated in the form of adaptive radiation following their arrival in Madagascar with novel ecological opportunities.

The time of radiation broadly coincides with that of lemurs and other mammals (Table 1 ). It is hence plausible that the radiation of Helictopleurini was triggered by the same conditions as the radiations of mammals, or indeed by the actual radiation of mammals. The latter is probable, considering that dung beetles are strongly dependent on mammals for their larval and adult resources. In Madagascar, lemurs are the most important mammalian group for dung beetles, as the use of ungulate and primate dung is the norm in Scarabaeidae and there are no native ungulates in Madagascar (apart from the now extinct hippopotami). Only specialized dung beetle species use carnivore or insectivore dung, while the use of carrion is more common (Cambefort, 1991c).

\subsection{Evolutionary ecology of Helictopleurini and related tribes}

The tribes Onthophagini and Oniticellini are widely distributed in Africa, Europe, Asia, and Americas, inhabiting both open habitats and forests (Barbero et al., 1999; Davis et al., 2002). Their main resource is ungulate dung, although the highly diverse Onthophagini also includes species feeding on carrion and even fungi and rotting fruits (Cambefort, 1991b; Hanski, 1989). Forest-dwelling dung beetles are typically strictly restricted to forests and hardly ever enter open areas even in close proximity to forests (Estrada and CoatesEstrada, 2002; Koivulehto, 2004; Spector and Ayzama, 2003). Longdistance dispersal is therefore much more likely for species inhabiting open areas. Concerning the colonization of Madagascar, open country species must be better able than forest species to tolerate arid conditions, such as encountered by the colonizers of western Madagascar. Paulian and Cambefort (1991) have previously suggested that ancestral Helictopleurini would have tolerated dryness and lived in open habitats, as many African Oniticellini do today.

Considering the colonization capacity of different kinds of species, and the feeding preferences of Oniticellini, Onthophagini and the basal Helictopleurini (Fig. 4), a likely hypothesis is that the ancestor of Helictopleurini lived in open habitats and fed on ungulate dung. In Madagascar, however, most of the resources were provided by forest-inhabiting mammals, especially lemurs (Goodman et al., 2003; Hawkins and Goodman, 2003; Pedrono and Smith, 2003), and subsequent evolution took Helictopleurini to forest habitats. Today, most species (72\%) occur in wet forests, and most of the rest occur in the various types of dry forest (the exceptional cattle dung beetles are discussed below). Habitat selection is apparently a relatively conservative trait, as there have been plenty of opportunities in the past 1500 years to use resources (cattle dung) in open areas in the mostly deforested Malagasy landscapes.

As there was no ungulate dung available in Madagascar, with the exception of hippopotami dung in riverine habitats, the ancestral Helictopleurini must have adapted to use other types of dung or carrion. Most of the species in the basal clades I and III use either primate dung or several types of dung, but other species, especially in the derived clade II, have adapted to use carrion as their main resource. The shift from dung to carrion has been proposed as an important adaptation explaining speciose 'dung beetle' assemblages in tropical forests in general, where large ungulates are less abundant than in savannas (Halffter, 1991). It thus appears that Helictopleurini in Madagascar have repeated the same adaptive shift that other tropical dung beetles have achieved multiple times elsewhere in the world. The Helictopleurini species have radiated to use a large range of resources, though most species have a relatively generalized diet. What is missing in Madagascar are, however, extreme specialists using rotting fruits and fungi. Such specialists occur elsewhere in the tropics (Cambefort, 1991a).

Body size in Helictopleurini shows highly significant differences between the clades, but within clades and between putative sister species pairs body size is much less variable. Clade I, consisting of large-bodied species with dissimilar diets, is basal in the phylogeny along with other clades of small species. The large derived clade II has medium-sized species by Malagasy standards. We suggest that, following colonization, directional selection increased body size in clade I to take advantage of the obvious empty niche for large dung beetles, provided by the now extinct Malagasy megafauna, especially the very large lemurs (up to the size of the gorilla). All tropical forest dung beetle communities around the world have largebodied species around $30 \mathrm{~mm}$ or larger in length (Hanski, 1989). The largest extant Malagasy species in clade I are substantially smaller, probably reflecting the impoverished community of 
Table 1

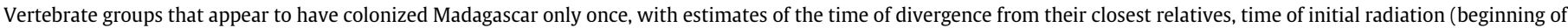
diversification in Madagascar), and possible subsequent radiations

\begin{tabular}{|c|c|c|c|c|}
\hline Faunal group & Divergence time & Initial radiation & Subsequent radiation(s) & Reference \\
\hline Day geckos & 7 & 5 & Out of Madagascar & Austin et al. (2004) \\
\hline Chameleons & $90-47$ & $68-35$ & $65-28$, and out of Madagascar & Raxworthy et al. (2002) \\
\hline Tortoises & $17.5-11.5$ & $14.5-9.5$ & Out of Madagascar & Palkovacs et al. (2002) \\
\hline Lemurs & 65,62 & 50,42 & $30-9$ & Yoder and Yang (2004); Poux et al. (2005) \\
\hline Tenrecs & 42 & 25 & - & Poux et al. (2005) \\
\hline Carnivores & 26 & 19 & - & Poux et al. (2005) \\
\hline Rodents & 24 & 20 & - & Poux et al. (2005) \\
\hline Dung beetles & $44-28$ & $37-23$ & $34-21$ & Present paper \\
\hline
\end{tabular}

The estimates given here are mean values based on combined data sets. The last line gives the respective data for Helictopleurini. Dates are given in MY.

large-bodied mammals and especially the lack of native ungulates in Madagascar.

In clade II, including generalist and carrion-feeding species, body size is significantly greater than in the closest clades III and IV with small coprophagous species, most likely because the bulk of the resources for the former species both allows and calls for larger body size for efficient handling. A trend of necrophagous species being larger than coprophagous ones is common in other tropical forest dung beetle communities (Feer and Pincebourde, 2005). Thus the adaptive radiation of Helictopleurini has produced similar patterns in terms of resource use and body size than what is known to occur in other tropical forest dung beetle communities. One important exception is nocturnal activity, which has not evolved in Helictopleurini though is common in e.g. Onthophagini (Cambefort, 1991c). A likely reason is the presence of large numbers of Canthonini in forests in Madagascar; the two tribes appear to have divided the diel niche among themselves (Viljanen, 2004).

Onthophagini have colonized Madagascar at least three times. In striking contrast to Helictopleurini, Onthophagini have not radiated in Madagascar, as indicated by the distant relationships among the endemic species (Paulian, 1987). The same applies to the tribe Scarabaeini, common in African savannas (Cambefort, 1991b) but represented by only three endemic species in Madagascar, most likely due to two or even three independent colonizations (unpubl. data). At the time of Onthophagini's arrival Helictopleurini would have already radiated, and most likely competition with Helictopleurini has prevented any radiation of Onthophagini to forests. Elsewhere in the world hundreds of Onthophagini species inhabit forests (Cambefort, 1991b). The colonists to Madagascar have most likely been species adapted to open habitats, but historical lack of abundant resources for dung beetles in open areas in Madagascar has apparently prevented radiation of Onthophagini and Scarabaeini in open habitats.

\subsection{A recent ecological shift}

An important new resource for dung beetles appeared about 1500 years ago, when humans brought cattle to Madagascar (Burney et al., 2003). Today cattle are very abundant, with about 10 million animals in open habitats across Madagascar and some low-density feral populations in many forest localities (Rahagalala et al., in preparation). Given that large ungulate dung including cattle dung is the preferred resource of thousands of dung beetles worldwide, the introduction of cattle to Madagascar represents a massive experiment with the Malagasy dung beetle fauna.

Opportunities for resource shift are greatest in forests, because the vast majority of Helictopleurini occur in forests. Elsewhere in tropical forests cattle dung pats would be full of dung beetles, but strikingly only three Helictopleurini species, $H$. rudicollis (a common generalist), $H$. nicollei, and the high-altitude cattle dung specialist $H$. sinuatocornis (which usually occurs in open habitats; below) have ever been sampled from cattle dung in wet forests.
Thus not a single case of diet shift to cattle dung has occurred among the 41 species inhabiting wet forests. Cattle dung is different in texture, fiber content, and the size of droppings compared to the other types of dung available in Madagascar, and apparently these differences are great enough to make the shift in resource use unlikely even in hundreds of generations and in spite of high level of resource competition among the species.

In contrast to the forest species, four species of Helictopleurini have shifted to use cattle dung in open habitats: $H$. neoamplicollis, $H$. quadripunctatus, $H$. sinuatocornis, and $H$. marsyas. Five other species have been recorded from cattle dung in open areas, but these observations are exceptional, the five species using mostly other resources in forests. Additionally, cattle dung in open habitats is used by a small number of endemic and introduced Onthophagini, two endemic Scarabaeini, and several Aphodiidae species (Rahagalala et al., in preparation). Aphodiidae, though abundant, are small in body size and typically inferior in competition to largebodied Scarabaeidae (Cambefort and Hanski, 1991). Altogether, local Scarabaeidae dung beetle communities in open habitats in Madagascar consist of 2-11 species (Rahagalala et al., in preparation), which is strikingly less than in cattle dung communities in mainland Africa, with typically $50-60$ or more locally coexisting species (Cambefort, 1991c).

Why and how have the four species of Helictopleurus made the shift to cattle dung in open areas? In the first place, we note that dung beetles living in closed forests, like most other tropical forest insects, are restricted to forests by high temperatures and low humidity in open areas (Koivulehto, 2004; Pineda et al., 2005). Helictopleurini are diurnal (Cambefort, 1991c; Viljanen, 2004), and hence they experience the maximal contrast in temperature and humidity between forests and open habitats. It is unlikely that wet forest species would shift to cattle dung in open areas, because in so doing they should change both their resource use and habitat selection. Therefore, it is likely that the species that have made the shift in resource use have been preadapted to dry habitats. Some of these species may have lived in dry forests, where dung would have been provided by lemurs as well as by the now extinct giant tortoises, elephant bird, and hippopotami, whose habitat appears to have been dry forests in south-eastern Madagascar (Goodman et al., 2003; Hawkins and Goodman, 2003; Pedrono and Smith, 2003). Five $H$. perrieri individuals have been found in tortoise dung, and on mainland Africa dung beetles are found in small numbers in ostrich and hippopotami dung (Davis et al., 2002; Gittings and Giller, 1998). Preadaptation to dry habitats is the likely scenario for the shift to cattle dung in open areas in $H$. neoamplicollis and $H$. quadripunctatus, as they have closely related species ( $H$. minutus and $H$. perrieri, respectively) living in dry forests in western Madagascar today.

The habitat and resource shift may have been facilitated by inhabiting high elevations, as the contrast between open habitats and closed forest in the abiotic conditions is less marked at high than at low elevations. This may have been the case with $H$. sinu- 
atocornis, which occurs, as an uncommon species, at high elevations along the western range boundary of its closest relative, $H$. giganteus, essentially in sympatry but in different habitat (open habitat versus forest). In the case of the fourth, widely distributed cattle dung beetle $H$. marsyas, the ability to use different kinds of food resources may have facilitated the shift. Its closest relative, $H$. nicollei, lives in lowland rain forest remnants within a small area on the east coast. A few individuals of $H$. nicollei have been collected in cattle dung in forests, and hence resource use is at least somewhat similar in this sister species pair. These species belong to clade I, which also includes $H$. sinuatocornis (above). All these species are large in body size, which may have facilitated the shift to cattle dung.

The recent shift of Helictopleurini to cattle dung has not involved speciation, with the possible exception of $H$. nicollei and $H$. marsyas, which are very similar morphologically, show very little molecular divergence, and may exemplify incipient speciation. The shift to cattle dung is nonetheless an interesting phenomenon, which has important consequences for the focal species and for the structure of the dung beetle community in open areas in Madagascar, with a mixture of endemic and intro- duced species. A shift in resource use potentially allows range expansion of species entering enemy and competition free space (Fraser and Lawton, 1994; Murphy, 2004). This appears to have happened in Helictopleurini, as three of the four cattle dung species now occur across all of Madagascar and have significantly larger geographical ranges than the forest-dwelling species. We suggest that this is due to relaxed competition in open areas, where cattle dung pats are relatively little used in comparison with the communities in mainland Africa and elsewhere in the tropics.

\section{Acknowledgments}

We thank Olivier Montreuil for help in identification and for the Asian beetle samples, Clarke Scholtz for the African beetle samples, Heidi Viljanen for help in the identification and comments on the manuscript, Chris Wheat for comments on the manuscript, Toshka Nyman for technical assistance, and Pierre Rahagalala for help in the field work. This study was funded by the Academy of Finland (Grant Nos. 64350, 20286 and 213457, Finnish Centre of Excellence Programme, 2000-08).

Appendix A. List of species used in the molecular phylogenetic analysis, with the morphological grouping by Lebis (1960) and Montreuil (2005b)

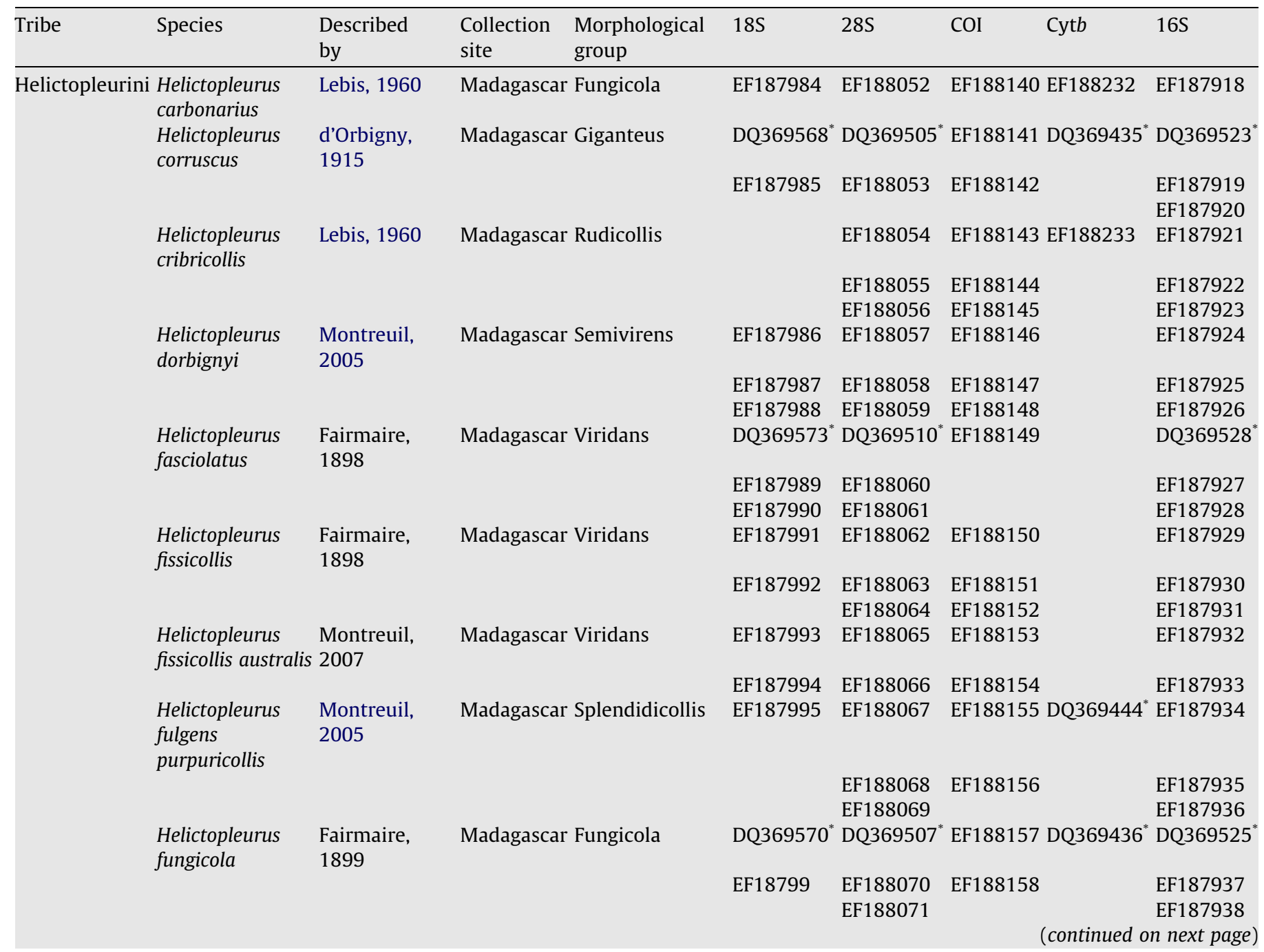


Appendix A. (continued)

\begin{tabular}{|c|c|c|c|c|c|c|c|c|}
\hline Tribe & Species & $\begin{array}{l}\text { Described } \\
\text { by }\end{array}$ & $\begin{array}{l}\text { Collection } \\
\text { site }\end{array}$ & $\begin{array}{l}\text { Morphological } \\
\text { group }\end{array}$ & $18 \mathrm{~S}$ & $28 \mathrm{~S}$ & Cytb & $16 \mathrm{~S}$ \\
\hline & $\begin{array}{l}\text { Helictopleurus } \\
\text { fungicola } \\
\text { peyrierasi }\end{array}$ & $\begin{array}{l}\text { Montreuil, } \\
2005\end{array}$ & \multirow{3}{*}{\multicolumn{3}{|c|}{ Madagascar Fungicola }} & EF188072 & EF188159 & EF187939 \\
\hline & & & & & & EF188073 & & EF187940 \\
\hline & & & & & & & & EF187941 \\
\hline & $\begin{array}{l}\text { Helictopleurus } \\
\text { giganteus }\end{array}$ & Harold, 1869 & \multirow{3}{*}{\multicolumn{2}{|c|}{ Madagascar Giganteus }} & DQ369571* & DQ369508* & EF188160 DQ369437* & DQ369526* \\
\hline & & & & & EF187997 & EF188074 & EF188161 & EF187942 \\
\hline & & & & & & EF188075 & EF188162 & EF187943 \\
\hline & $\begin{array}{l}\text { Helictopleurus } \\
\text { marsyas }\end{array}$ & Olivier, 1789 & \multirow{3}{*}{\multicolumn{2}{|c|}{ Madagascar Giganteus }} & DQ369572* & DQ369509* & EF188163 DQ369438* & DQ369527* \\
\hline & & & & & EF187998 & EF188076 & EF188164 & EF187944 \\
\hline & & & & & & EF188077 & EF188165 & EF187945 \\
\hline & $\begin{array}{l}\text { Helictopleurus } \\
\text { minutus }\end{array}$ & $\begin{array}{l}\text { Montreuil, } \\
2007\end{array}$ & \multicolumn{2}{|c|}{ Madagascar Viridiflavus } & & EF188078 & EF188234 & EF187946 \\
\hline & $\begin{array}{l}\text { Helictopleurus } \\
\text { neoamplicollis }\end{array}$ & Krell, 2000 & \multirow{4}{*}{\multicolumn{2}{|c|}{ Madagascar Fungicola }} & DQ369574* & DQ369511* & EF188166 DQ369440* & DQ369529* \\
\hline & & & & & EF187999 & EF188079 & EF188167 & EF187947 \\
\hline & & & & & EF188000 & EF188080 & EF188168 & EF187948 \\
\hline & & & & & & EF188081 & & \\
\hline & $\begin{array}{l}\text { Helictopleurus } \\
\text { neuter }\end{array}$ & $\begin{array}{l}\text { Fairmaire, } \\
1898\end{array}$ & \multirow{3}{*}{\multicolumn{2}{|c|}{ Madagascar Viridans }} & & EF188082 & EF188169 EF188235 & EF187949 \\
\hline & & & & & & EF188083 & EF188170 & EF187950 \\
\hline & & & & & & EF188084 & EF188171 & EF187951 \\
\hline & $\begin{array}{l}\text { Helictopleurus } \\
\text { nicollei }\end{array}$ & Lebis, 1960 & \multirow{2}{*}{\multicolumn{2}{|c|}{ Madagascar Giganteus }} & DQ369575* & DQ369512* & EF188172 DQ369441* & DQ369530* \\
\hline & & & & & EF188001 & EF188085 & EF188173 & EF187952 \\
\hline & $\begin{array}{l}\text { Helictopleurus } \\
\text { perrieri }\end{array}$ & $\begin{array}{l}\text { Fairmaire, } \\
1898\end{array}$ & \multirow{3}{*}{\multicolumn{2}{|c|}{ Madagascar Quadripunctatus }} & DQ369577* & DQ369514* & EF188174 DQ369443* & DQ369532* \\
\hline & & & & & EF188002 & EF188086 & EF188175 & EF187953 \\
\hline & & & & & EF188003 & EF188087 & EF188176 & EF187954 \\
\hline & $\begin{array}{l}\text { Helictopleurus } \\
\text { politicollis }\end{array}$ & $\begin{array}{l}\text { Fairmaire, } \\
1902\end{array}$ & \multirow{3}{*}{\multicolumn{2}{|c|}{ Madagascar Splendidicollis }} & DQ369578* & DQ369515* & EF188177 EF188236 & DQ369533* \\
\hline & & & & & EF188004 & EF188088 & EF188178 & EF187955 \\
\hline & & & & & EF188005 & EF188089 & EF188179 & EF187956 \\
\hline & $\begin{array}{l}\text { Helictopleurus } \\
\text { quadripunctatus }\end{array}$ & Olivier, 1789 & \multirow{3}{*}{\multicolumn{2}{|c|}{ Madagascar Quadripunctatus }} & EF188006 & EF188090 & EF188180 EF188237 & EF187957 \\
\hline & & & & & EF188007 & EF188091 & EF188181 & EF187958 \\
\hline & & & & & EF188008 & EF188092 & EF188182 & EF187959 \\
\hline & $\begin{array}{l}\text { Helictopleurus } \\
\text { rudicollis }\end{array}$ & $\begin{array}{l}\text { Fairmaire, } \\
1898\end{array}$ & \multirow{3}{*}{\multicolumn{2}{|c|}{ Madagascar Rudicollis }} & DQ369580* & DQ369517* & EF188183 EF188238 & DQ369535* \\
\hline & & & & & EF188009 & EF188093 & EF188184 & EF187960 \\
\hline & & & & & EF188010 & EF188094 & & EF187961 \\
\hline & $\begin{array}{l}\text { Helictopleurus } \\
\text { semivirens }\end{array}$ & $\begin{array}{l}\text { d'Orbigny, } \\
1915\end{array}$ & \multirow{2}{*}{\multicolumn{2}{|c|}{ Madagascar semivirens }} & EF188011 & EF188095 & EF188186 & EF187962 \\
\hline & & & & & EF188012 & EF188096 & EF188187 & EF187963 \\
\hline & $\begin{array}{l}\text { Helictopleurus } \\
\text { sinuatocornis }\end{array}$ & $\begin{array}{l}\text { Fairmaire, } \\
1898\end{array}$ & \multirow{2}{*}{\multicolumn{2}{|c|}{ Madagascar Giganteus }} & DQ369582* & DQ369519* & EF188189 DQ369445* & DQ369537* \\
\hline & & & & & EF188014 & EF188098 & EF188190 & EF187965 \\
\hline & $\begin{array}{l}\text { Helictopleurus } \\
\text { splendidicollis }\end{array}$ & $\begin{array}{l}\text { Fairmaire, } \\
1893\end{array}$ & \multirow[t]{3}{*}{ Madagascar } & Splendidicollis & DQ369583* & DQ369520* & EF188191 DQ369446* & DQ369538* \\
\hline & & & & & EF188015 & EF188099 & EF188192 & EF187966 \\
\hline & & & & & EF188016 & EF188100 & & EF187967 \\
\hline & $\begin{array}{l}\text { Helictopleurus } \\
\text { steineri }\end{array}$ & $\begin{array}{l}\text { Paulian and } \\
\text { Cambefort, } \\
1991\end{array}$ & \multirow[t]{3}{*}{ Madagascar } & Semivirens & EF188017 & EF188101 & EF188193 EF188239 & EF187968 \\
\hline & & & & & EF188018 & EF188102 & EF188194 & EF187969 \\
\hline & & & & & EF188019 & EF188103 & EF188195 & EF187970 \\
\hline & $\begin{array}{l}\text { Helictopleurus } \\
\text { unifasciatus }\end{array}$ & $\begin{array}{l}\text { Fairmaire, } \\
1901\end{array}$ & \multirow[t]{3}{*}{ Madagascar } & Splendidicollis & DQ369584* & DQ369521* & EF188196 DQ369447" & DQ369539* \\
\hline & & & & & EF188020 & EF188104 & EF188197 & EF187971 \\
\hline & & & & & EF188021 & EF188105 & EF188198 & EF187972 \\
\hline
\end{tabular}


Appendix A. (continued)

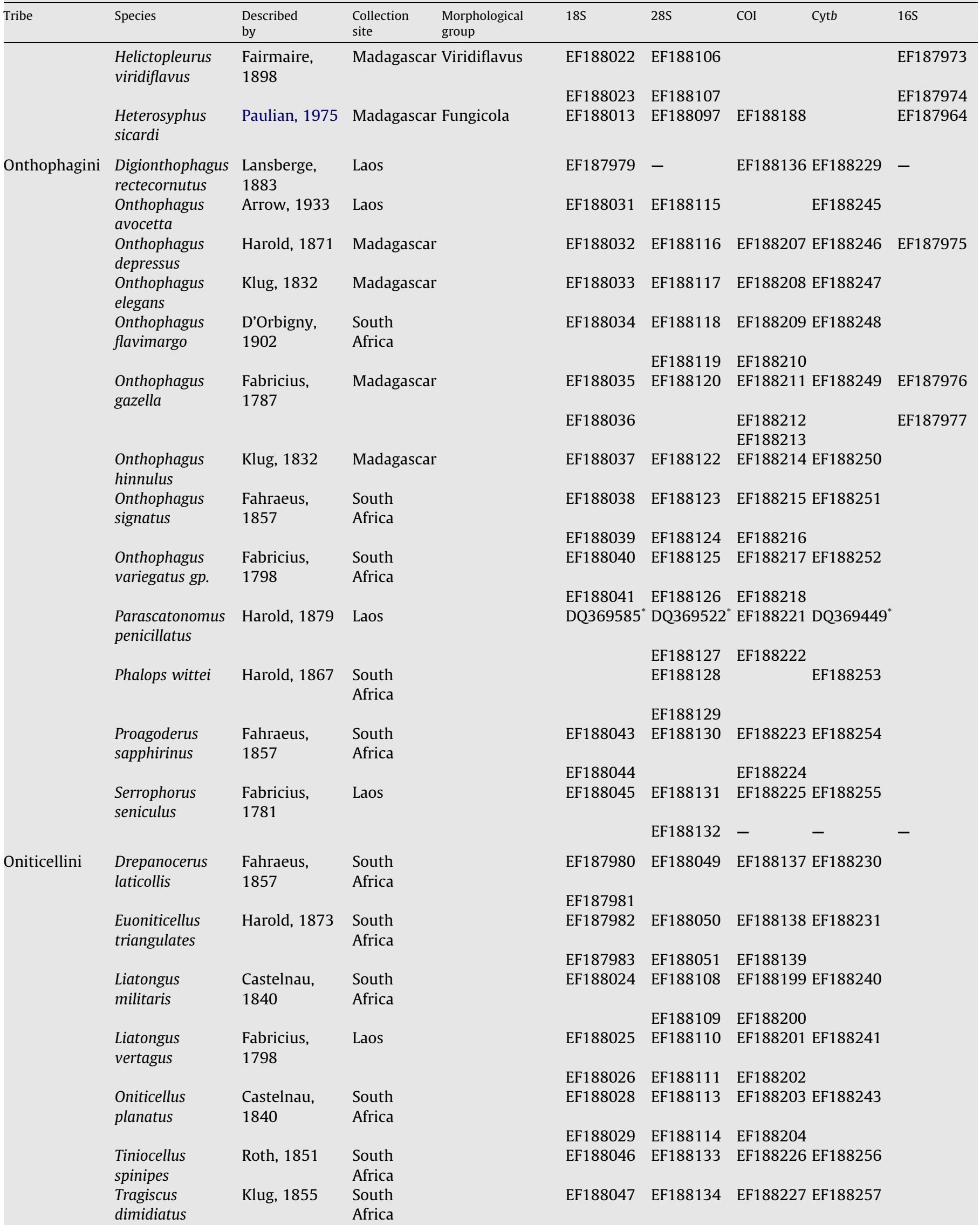




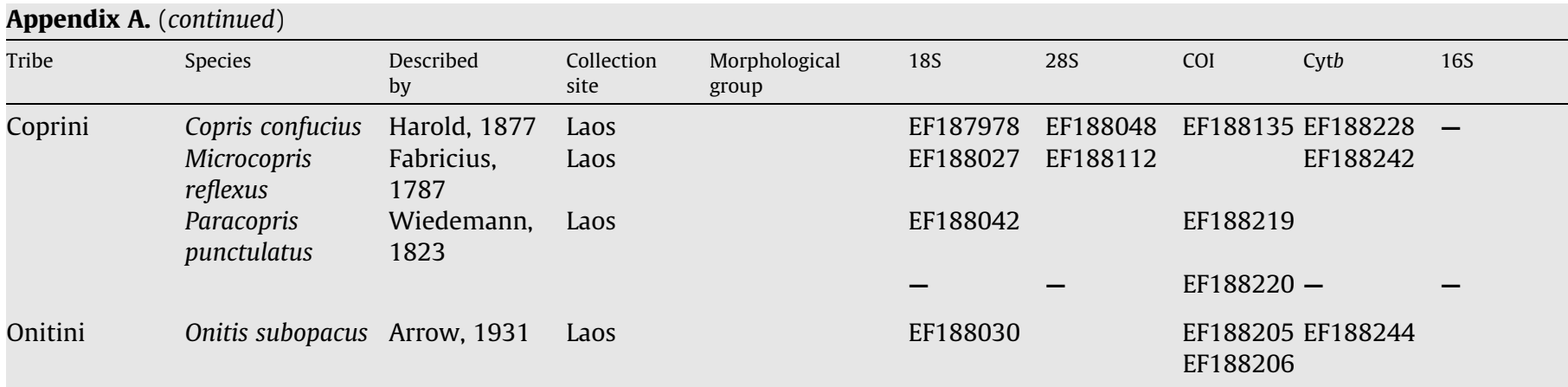

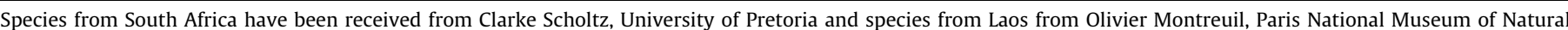
History. GenBank accession numbers for the sequences are provided, and those published in Orsini et al. (2007) are marked with an asterisk.

Appendix B. List of genomic regions used with their length in basepairs and percentage of conservative, variable, parsimony informative and singleton sites

\begin{tabular}{lllcrr}
\hline Gene & Basepairs & Conservative & Variable & Parsimony informative & Singleton \\
\hline $28 S$ & 314 & 85.7 & 13.7 & 10.2 & 3.5 \\
$18 \mathrm{~S}$ & 818 & 94.9 & 4.9 & 2.2 & 2.7 \\
$16 \mathrm{~S}$ & 373 & 60.1 & 38.6 & 29.8 & 8.3 \\
COI & 770 & 54.0 & 46.0 & 37.3 & 8.7 \\
Cytb & 333 & 48.0 & 52.0 & 44.7 & 7.2 \\
\hline
\end{tabular}

\section{References}

Andresen, E., 2002a. Dung beetles in a Central Amazonian rainforest and their ecological role as secondary seed dispersers. Ecol. Entomol. 27, 257-270.

Andresen, E., 2002b. Primary seed dispersal by red howler monkeys and the effect of defecation patterns on the fate of dispersed seeds. Biotropica 34, 261-272.

Austin, J.J., Arnold, E.N., Jones, C.G., 2004. Reconstructing an island radiation using ancient and recent DNA: the extinct and living day geckos (Phelsuma) of the Mascarene islands. Mol. Phylogenet. Evol. 31, 109-122.

Baldwin, B.C., 1997. Adaptive radiation of the Hawaiian silversword alliance: congruence and conflict of phylogenetic evidence from molecular and nonmolecular investigations. In: Givnish, T.J., Systma, K.J. (Eds.), Molecular Evolution and Adaptive Radiation. Cambridge University Press, Cambridge, pp. 104-128.

Barbero, E., Palestrini, C., Rolando, A., 1999. Dung beetle conservation: effects of habitat and resource selection (Coleoptera: Scarabaeoidea). J. Insect Conserv., 75-84.

Barrier, M., Baldwin, B.G., Robichaux, R.H., Purugganan, M.D., 1999. Interspecific hybrid ancestry of a plant adaptive radiation: Allopolyploidy of the Hawaiian silversword alliance (Asteraceae) inferred from floral homeotic gene duplications. Mol. Biol. Evol. 16, 1105-1113.

Briggs, J.C., 2003. The biogeographic and tectonic history of India. J. Biogeogr. 30, 381-388.

Brower, A.V., 1994. Rapid morphological radiation and convergence among races of the butterfly Heliconius erato inferred from patterns of mitochondrial DNA evolution. Proc. Natl. Acad. Sci. USA 91, 6491-6495.

Browne, D.J., Scholtz, C.H., 1995. Phylogeny of the families of Scarabaeoidea (Coleoptera) based on characters of the hindwing articulation, hindwing base and wing venation. Syst. Entomol. 20, 145-173.

Browne, J., Scholtz, C.H., 1998. Evolution of the scarab hindwing articulation and wing base: a contribution toward the phylogeny of the Scarabaeoidea (Scarabaeoidea: Coleoptera). Syst. Entomol. 23, 307-326.

Burney, D.A., Burney, L.P., Godfrey, L.R., Jungers, W.L., Goodman, S.M., Wright, H.T., Jull, A.J., 2004. A chronology for late prehistoric Madagascar. J. Hum. Evol. 47, 25-63.

Burney, D.A., Robinson, G.S., Burney, L.P., 2003. Sporormiella and the late Holocene extinctions in Madagascar. Proc. Natl. Acad. Sci. USA 100, 10800-10805.

Cabrero-Sanudo, F.J., Zardoya, R., 2004. Phylogenetic relationships of Iberian Aphodiini (Coleoptera: Scarabaeoidea) based on morphological and molecular data. Mol. Phylogenet. Evol. 31, 1084-1100.

Cambefort, Y., 1991a. From saprophagy to coprophagy. In: Hanski, I. Cambefort, Y. (Eds.), Dung Beetle Ecology. Princeton University Press, Princeton, pp. 22-35.

Cambefort, Y., 1991b. Biogeography and evolution. In: Hanski, I., Cambefort, Y. (Eds.), Dung Beetle Ecology. Princeton University Press, Princeton, pp. 51-68.

Cambefort, Y., 1991c. Dung beetles in tropical Savannas. In: Hanski, I., Cambefort, Y. (Eds.), Dung Beetle Ecology. Princeton University Press, Princeton, pp. 156-178.
Cambefort, Y., Hanski, I., 1991. Dung beetle population biology. In: Hanski, I. Cambefort, Y. (Eds.), Dung Beetle Ecology. Princeton University Press, Princeton, pp. 36-50.

d'Orbigny, H., 1915. Synopsis dun genre nouveau d́Oniticellides (Scarabaeidae Coprini) spécial à Madagascar. Ann. Soc. Entomol. Fr. 84, 402-434.

Davis, A.L.V., Scholtz, C.H., 2001. Historical vs. ecological factors influencing global patterns of scarabaeine dung beetle diversity. Divers. Distribut. 7, 161-174.

Davis, A.L.V., Scholtz, C.H., Philips, T.K., 2002. Historical biogeography of scarabaeine dung beetles. J. Biogeogr. 29, 1217-1256.

de Wit, M.J., 2003. Madagascar: Heads its a Continent, tails its an Island. Ann. Rev. Earth Planet Sci. 31, 213-248.

Despres, L., Cherif, M., 2004. The role of competition in adaptive radiation: a field study on sequentially ovipositing host-specific seed predators. J. Anim. Ecol. 73, 109-116.

Drummond, A., Rambaut, A., 2002-2006. BEAST v1.4 Bayesian Evolutionary Analysis Sampling Trees. University of Oxford.

Drummond, A.J., Ho, S.Y.W., Phillips, M.J., Rambaut, A., 2006. Relaxed phylogenetics and dating with confidence. PLoS Biol. 4, 699-710.

Emerson, B.C., 2002. Evolution on oceanic islands: molecular phylogenetic approaches to understanding pattern and process. Mol. Ecol. 11, 951-966.

Estrada, A., Coates-Estrada, R., 2002. Dung beetles in continuous forest, forest fragments and in an agricultural mosaic habitat island at Los Tuxtlas, Mexico. Biodivers. Conserv. 11, 1903-1918.

Farrell, B.D., 2001. Evolutionary assembly of the milkweed fauna: cytochrome oxidase I and the age of Tetraopes beetles. Mol. Phylogenet. Evol. 18, 467-478.

Feer, F., Pincebourde, S., 2005. Diel flight activity and ecological segregation within an assemblage of tropical forest dung and carrion beetles. J. Trop. Ecol. 21, 2130.

Fisher, B.L., 1997. Biogeography and ecology of the ant fauna of Madagascar (Hymenoptera: Formicidae). J. Nat. Hist. 31, 269-302.

Fraser, S.M., Lawton, J.H., 1994. Host-range expansion by British moths onto introduced conifers. Ecol. Entomol. 19, 127-137.

Gittings, T., Giller, P., 1998. Resource quality and the colonisation and succession of coprophagous dung beetles. Ecography 21, 581-592.

Goloboff, P., 1999. NONA (NO NAME) ver. 2. Published by the author, Tucúman, Argentina.

Goodman, S.M., Ganzhorn, J.U., Rakotondravony, D., 2003. Introduction to the mammals. In: Goodman, S.M., Benstead, J.P. (Eds.), The Natural History of Madagascar. The University of Chigago Press, Chigago, pp. 1159-1186.

Halffter, G., 1991. Historical and ecological factors determining the geographica distribution of beetles (Coleoptera: Scarabaeiadae: Scarabaeinae). Folia Entomol. Mex. 82, 195-238.

Hall, T., 1999. BioEdit: a user-friendly biological sequence alignment editor and analysis program for Windows 95/98/NT. Nucleic Acids Symp. Ser., 95-98.

Hanski, I., 1989. Dung beetles. In: Lieth, H., Werger, M.J.A. (Eds.), Tropical Rain Forest Ecosystems. Elsevier Science Publishers, Amsterdam, pp. 489-511. 
Hanski, I., Cambefort, Y., 1991. Competition in dung beetles. In: Hanski, I., Cambefort, Y. (Eds.), Dung Beetle Ecology. Princeton University Press, Princeton, pp. 305-329.

Hanski, I., Koivulehto, H., Cameron, A., Rahagalala, P., 2007. Deforestation and apparent extinctions of endemic forest beetles in Madagascar. Biol. Lett. doi:10.1098/rsbl.2007.0043.

Hawkins, A., Goodman, S.M., 2003. Introduction to the birds. In: Ganzhorn, J.U. Benstead, J.P. (Eds.), The Natural History of Madagascar. The University of Chigago Press, Chigago, pp. 1019-1044.

Jameson, M., Ratcliffe, B., 2005. Generic Guide to New World Scarab Beetles. UNL State Museum-Division of Entomology.

Juan, C., Oromi, P., Hewitt, G.M., 1995. Mitochondrial-DNA Phylogeny and Sequential Colonization of Canary-Islands by Darkling Beetles of the Genus Pimelia (Tenebrionidae). Proc. R. Soc. Lond. B Biol. 261, 173-180.

Kluge, A.G., 1989. A concern for evidence and a phylogenetic hypothesis of relationships among Epicrates (Boidae, Serpentes). Syst. Zool. 38, 7-25.

Koivulehto, H., 2004. Madagascar's Dung Beetles-Rain Forest Species Avoid Open Areas. Biological and Environmental Sciences. University of Helsinki, Helsinki. p.

Kumar, S., Tamura, K., Nei, M., 2004. MEGA3: Integrated software for Molecular Evolutionary Genetics Analysis and sequence alignment. Brief Bioinform. 5, 150 163.

Lebis, E., 1960. Helictopleurina. In: Paulian, R. (Ed.), Insectes Coléoptères Scarabaeidae. L'Institut de Recherche Scientifique Tananarive-Tsimbazaza, Tananarive, p. 130.

Leys, R., Watts, C.H.S., Cooper, S.J.B., Humphreys, W.F., 2003. Evolution of subterranean diving beetles (Coleoptera: Dytiscidae: Hydroporini, Bidessini) in the arid zone of Australia. Evolution 57, 2819-2834.

Losos, J.B., 1990a. Ecomorphology, performance capability, and scaling of WestIndian Anolis lizards-an evolutionary analysis. Ecol. Monogr. 60, 369-388.

Losos, J.B., 1990b. The evolution of form and function-morphology and locomotor performance in West-Indian Anolis Lizards. Evolution 44, 1189-1203.

Losos, J.B., Irschick, D.J., 1996. The effect of perch diameter on escape behaviour of Anolis lizards: laboratory predictions and field tests. Anim. Behav. 51, 593-602.

Mittal, I.C., 1993. Natural manuring and soil conditioning by dung beetles. Trop. Ecol. 34, 150-159.

Monaghan, M.T., Gattolliat, J.L., Sartori, M., Elouard, J.M., James, H., Derleth, P., Glaizot, O., de Moor, F., Vogler, A.P., 2005. Trans-oceanic and endemic origins of the small minnow mayflies (Ephemeroptera, Baetidae) of Madagascar. Proc. Biol. Sci. 272, 1829-1836.

Monaghan, M.T., Inward, D.J., Hunt, T., Vogler, A.P., 2007. A molecular phylogenetic analysis of the Scarabaeinae (dung beetles). Mol Phylogenet. Evol. doi:10.1016/ j.ympev.2007.1006.1009.

Montreuil, O., 2005a. Contribution à létude du genre Helictopleurus d'Orbigny, 1915 (Coleoptera, Scarabaeidae). Bull. Soc. Entomol. Fr. 110, 373-376.

Montreuil, O., 2005b. New Helictopleurus d'Orbigny, 1915 from Madagascar, and review of the "semivirens group" sensu Lebis, 1960 (Insecta, Coleoptera, Scarabaeidae, Oniticellini). Zoosystema 27, 123-135.

Montreuil, O., 2006. Contribution à létude des Canthonini de Madagascar (6e note): mises au point taxonomiques et nomenclaturales et desription de nouvelles espèces du genre Arachnodes Westwood, 1847 (Coleoptera, Scarabaeidae). Rev. Fr. Entomol. 28, 97-110.

Montreuil, O., 2007. Nouveaux Helictopleurus dorbigny 1915. Bull. Soc. Entomol. Fr. $1,79-84$

Murphy, S.M., 2004. Enemy-free space maintains swallowtail butterfly host shift. Proc. Natl. Acad. Sci. USA 101, 18048-18052.

Myers, N., Mittermeier, R.A., Mittermeier, C.G., da Fonseca, G.A.B., Kent, J., 2000 Biodiversity hotspots for conservation priorities. Nature 403, 853-858.

Nagy, Z.T., Joger, U., Wink, M., Glaw, F., Vences, M., 2003. Multiple colonization of Madagascar and Socotra by colubrid snakes: evidence from nuclear and mitochondrial gene phylogenies. Proc. Biol. Sci. 270, 2613-2621.

Nee, S., Mooers, A.O., Harvey, P.H., 1992. Tempo and mode of evolution revealed from molecular phylogenies. Proc. Natl. Acad. Sci. USA 89, 8322-8326.

Nixon, K.C., 2002. WinClada ver. 1.00.00. Published by the author, Ithaca, NY.

Noonan, B.P., Chippindale, P.T., 2006. Vicariant origin of malagasy reptiles supports late cretaceous antarctic land bridge. Am. Nat. 168, 730-741.

Orsini, L., Koivulehto, H., Hanski, I., 2007. Molecular evolution and radiation of dung beetles in Madagascar. Cladistics 23, 145-168.

Palkovacs, E.P., Gerlach, J., Caccone, A., 2002. The evolutionary origin of Indian Ocean tortoises (Dipsochelys). Mol. Phylogenet. Evol. 24, 216-227.

Paulian, R., 1975. On some mountain Canthonina [Coleoptera Scarabaeidae] from Madagascar. Ann. Soc. Entomol. Fr. 11, 221-252.

Paulian, R., 1986. Catalogue des Coleopteres Scarabaeidae de Madagascar. Bull Acad. Malgache 62, 89-111.

Paulian, R., 1987. The Scarabaeidae beetles of some tropical Islands. Br. Soc. Zool. Fr. $112,255-275$.

Paulian, R., Cambefort, Y., 1991. Remarques sur le genre Helictopleurus et description de trois nouvelles espèces (Coleoptera, Scarabaeidae). Rev. Fr. Entomol. 13, 113-118.

Pedrono, M., Smith, L., 2003. Testunidae, land Tortoises. In: Ganzhorn, J.U., Benstead, J.P. (Eds.), The Natural History of Madagascar. The University of Chigago Press, Chigago, pp. 951-955.
Philips, T.K., Pretorius, E., Scholtz, C.H., 2004. A phylogenetic analysis of dung beetles (Scarabaeinae: Scarabaeidae): unrolling an evolutionary history. Invert. Syst. $18,53-88$.

Pineda, E., Moreno, C., Escobar, F., Halffter, G., 2005. Frog, bat, and dung beetle diversity in the cloud forest and coffee agroecosystems of Veracruz, Mexico. Conserv. Biol. 19, 400-410.

Posada, D., Crandall, K.A., 1998. MODELTEST: testing the model of DNA substitution. Bioinformatics 14, 817-818.

Poux, C., Madsen, O., Marquard, E., Vieites, D.R., de Jong, W.W., Vences, M., 2005. Asynchronous colonization of Madagascar by the four endemic clades of primates, tenrecs, carnivores, and rodents as inferred from nuclear genes. Syst. Biol. 54, 719-730.

Rahagalala, P., Viljanen, H., Hanski, I, Hottola, J. in preparation. Assemblages of dung beetles using introduced cattle dung in Madagascar.

Rambaut, A., Drummond, A., 2003. MCMC Trace Analysis Tool. University of Oxford

Raxworthy, C.J., Forstner, M.R., Nussbaum, R.A., 2002. Chameleon radiation by oceanic dispersal. Nature 415, 784-787.

Ribera, I., Vogler, A.P., 2004. Speciation of Iberian diving beetles in Pleistocene refugia (Coleoptera, Dytiscidae). Mol. Ecol. 13, 179-193.

Ronquist, F., Huelsenbeck, J.P., 2003. MrBayes 3: Bayesian phylogenetic inference under mixed models. Bioinformatics 19, 1572-1574.

Sakai, A.K., Weller, S.G., Wagner, W.L., Soltis, D.E., 1997. Phylogenetic perspective on the evolution of dioecy: adaptive radiation in the endemic Hawaiina genera Schiedea and Alsinidendron (Caryophyllaceae: Alsinoideae). In: Givnish, T.J., Systma, K.J. (Eds.), Molecular Evolution and Adaptive Radiation. Cambridge University Press, Cambridge, pp. 455-473.

Sato, A., Tichy, H., O'hUigin, C., Grant, P.R., Grant, B.R., Klein, J., 2001. On the origin of Darwin's finches. Mol. Biol. Evol. 18, 299-311.

Schluter, D., 1996. Ecological causes of adaptive radiation. Am. Nat. 148, S40-S64.

Schluter, D., 2000. The Ecology of Adaptive Radiation. Oxford University Press.

Simon, C., Frati, F., Beckenbach, A., Crespi, B., Liu, H., Flook, P., 1994. Evolution, weighting, and phylogenetic utility of mitochondrial gene-sequences and a compilation of conserved polymerase chain-reaction primers. Ann. Entomol. Soc. Am. 87, 651-701.

Smith, A.B., Hawks, D.C., Heraty, J.M., 2006. An overview of the classification and evolution of the major scarab beetle clades (Coleoptera: Scarabaeoidea) based on preliminary molecular analyses. Coleopterists Soc. Monogr. 5, 3546.

Smith, C.I., Farrell, B.D., 2005. Range expansions in the flightless longhorn cactus beetles, Moneilema gigas and Moneilema armatum, in response to Pleistocene climate changes. Mol. Ecol. 14, 1025-1044.

Sparks, J.S., Smith, W.L., 2004. Phylogeny and biogeography of the Malagasy and Australasian rainbowfishes (Teleostei: Melanotaenioidei): Gondwanan vicariance and evolution in freshwater. Mol. Phylogenet. Evol. 33, 719-734.

Spector, S., Ayzama, S., 2003. Rapid turnover and edge effects in dung beetle assemblages (Scarabaeidae) at a Bolivian Neotropical forest-savanna ecotone. Biotropica 35, 394-404.

Tello, J.G., Bates, J.M., 2007. Molecular phylogenetics of the tody-tyrant and flatbill assemblage of tyrant flycatchers (Tyrannidae). Auk 124, 134-154.

Thompson, J.D., Higgins, D.G., Gibson, T.J., 1994. CLUSTAL W: improving the sensitivity of progressive multiple sequence alignment through sequence weighting, position-specific gap penalties and weight matrix choice. Nucleic Acids Res., 4673-4680.

Torres, E., Lees, D.C., Vane-Wright, R.I., Kremen, C., Leonard, J.A., Wayne, R.K., 2001 Examining monophyly in a large radiation of Madagascan butterflies (Lepidoptera: Satyrinae: Mycalesina) based on mitochondrial DNA data. Mol. Phylogenet. Evol. 20, 460-473.

Weller, S.G., Sakai, A.K., Wagner, W.L., Herbst, D.R., 1990. Evolution of dioecy in Schiedea (Caryophyllaceae: Alsinoideae) in the Hawaiian islands: biogeographical and ecological factors. Syst. Bot. 15, 266-276.

Vences, M., Vieites, D.R., Glaw, F., Brinkmann, H., Kosuch, J., Veith, M., Meyer, A., 2003. Multiple overseas dispersal in amphibians. Proc. Biol. Sci. 270, 24352442 .

Viljanen, H., 2004. Diet Specialization Among Endemic Forest Dung Beetles in Madagascar. Biological and Environmental Sciences. University of Helsinki, Helsinki.

Viljanen, H., Wirta, H., Montreuil, O., Rahagalala, P., Johnson, S., Hanski, I. in preparation. Description of dung beetle communities in northeast and southeast Madagascar.

Villalba, S., Lobo, J.M., Martin-Piera, F., Zardoya, R., 2002. Phylogenetic relationships of Iberian dung beetles (Coleoptera: scarabaeinae): insights on the evolution of nesting behavior. J. Mol. Evol. 55, 116-126.

Yoder, A.D., Nowak, M.D., 2006. Has vicariance or dispersal been the predominant biogeographic force in Madagascar? Only time will tell. Ann. Rev. Ecol. Evol. Syst. 37, 405-431.

Yoder, A.D., Yang, Z., 2004. Divergence dates for Malagasy lemurs estimated from multiple gene loci: geological and evolutionary context. Mol. Ecol. 13, 757-773.

Zakharov, E.V., Smith, C.R., Lees, D.C., Cameron, A., Vane-Wright, R.I., Sperling, F.A.H., 2004. Independent gene phylogenies and morphology demonstrate a Malagasy origin for a wide-ranging group of swallowtail butterflies. Evolution 58, 27632782 